\title{
PEMBELAJARAN ILMU PENGETAHUAN SOSIAL UNTUK PESERTA DIDIK DI SEKOLAH DASAR
}

\author{
Kustiyono \\ SDN Anyelir 1 Kota Depok \\ kustiyonoessa@gmail.com
}

\begin{abstract}
Abstrak : Kajian ini membahas mengenai model pembelajaran mata pelajaran ilmu pendidikan sosial untuk peserta didik sekolah dasar dan madrasah ibtidaiyah. Penelitian ini menggunakan pendekatan kualitatif menggunakan kajian kepustakaan. Pembelajaran Pendidikan IPS lebih menekankan pada aspek pendidikan daripada transfer konsep, karena dalam pembelajaran pendidikan IPS peserta didik diharapkan memperoleh pemahaman terhadap sejumlah konsep dan mengembangkan serta melatih sikap, nilai, moral, dan keterampilannya berdasarkan konsep yang telah dimilikinya. Sehingga mampu mengarahkan peserta didik menjadi pribadi yang mandiri, kritis, kreatif dan adaptif. Sedangkan tujuan pembelajaran IPS di MI adalah untuk member bekal kemampuan dasar kepada peserta didik untuk mengembangkan diri sesuai bakat, minat, kemampuan dan lingkunganya dalam bidang pembelajaran
\end{abstract}

Kata Kunci : Model, Pembelajaran, Ilmu Pendidikan Sosial, dan Sekolah Dasar

Abstract: This study discusses the learning model of social education subjects for elementary school students and madrasah Ibtidaiyah. This research uses a qualitative approach using a literature study. Social studies education emphasizes more on the aspect of education than the transfer of concepts because in learning social studies education students are expected to gain an understanding of some concepts and develop and practice their attitudes, values, morals, and skills based on the concepts they have. To be able to direct students to become independent, critical, creative, and adaptive. While the purpose of social studies learning in MI is to provide basic skills to students to develop themselves according to their talents, interests, abilities, and environment in the field of learning

Keywords: Model, Learning, Social Education, and Elementary School

\section{PENDAHULUAN}

Menurut Undang-Undang Nomor 20 Tahun 2003 tentang Sistem Pendidikan Nasional pasal 1 ayat 1 , bahwa pendidikan adalah usaha sadar dan terencana untuk mewujudkan suasana belajar dan proses pembelajaran agar peserta didik secara aktif mengembangkan potensi dirinya untuk memiliki kekuatan spiritual, keagamaan, pengendalian diri, kepribadian, akhlak mulia serta keterampilan yang diperlukan dirinya, masyarakat, bangsa, dan Negara [1].

Pendidikan sebagai institusi utama untuk membentuk sumber daya masyarakat yang berkualitas demi kepentingan masa depan suatu negara. Pendidikan mempunyai peranan dalam membentuk kualitas sumber daya manusia dan mengembangkan potensi peserta didik untuk menyelesaikan permasalahan di 
masa mendatang dalam rangka mendukung pembangunan bangsa Indonesia [2]. Hal ini sesuai dengan fungsi dan tujuan pendidikan nasional yang tercantum dalam Undang-Undang Nomor 20 Tahun 2003 menyebutkan bahwa pendidikan nasional berfungsi mengembangkan kemampuan dan membentuk watak serta peradaban bangsa yang bermartabat dalam rangka mencerdaskan kehidupan bangsa, bertujuan untuk berkembangnya potensi siswa agar menjadi manusia yang beriman dan bertakwa kepada Tuhan Yang Maha Esa, berakhlak mulia, sehat, berilmu, cakap, kreatif, mandiri, dan menjadi warga Negara yang demokratis serta bertanggung jawab [3]

Pengetahuan dan pengembangan potensi diri dapat dimulai dari Pendidikan Dasar. Hal tersebut sesuai dalam Undang-Undang Nomor 17 Tahun 2010 tentang pengelolaan dan penyelenggaraan pendidikan pasal 1 ayat 7, menyebutkan bahwa pendidikan dasar adalah jenjang pendidikan pada jalur pendidikan formal yang melandasi jenjang pendidikan menengah yang diselenggarakan pada satuan pendidikan berbentuk Sekolah Dasar dan Madrasah Ibtidaiyah atau bentuk lain sederajat serta menjadi satu kesatuan kelanjutan pendidikan pada satuan pendidikan yang berbentuk sekolah menengah pertama dan Madrasah Tsanawiyah, atau bentuk lain yang sederajat [4]

Pendidikan dasar tidak dapat terlepas dari kurikulum. Menurut Peraturan Pemerintah Nomor 32 Tahun 2013 pasal 1 ayat 16 menyatakan bahwa kurikulum adalah seperangkat rencana dan pengaturan mengenai tujuan, isi, dan bahan pelajaran serta cara yang digunakan sebagai pedoman penyelenggaraan kegiatan pembelajaran untuk mencapai tujuan pendidikan tertentu[5] Penggunaan kurikulum yang tepat akan mengantarkan siswa memperoleh pengetahuan sehingga potensi-potensi yang dimiliki dapat berkembang untuk mencapai tujuan yang diharapkan [6]

Setiap usaha pendidikan memiliki tujuan tertentu yang ingin dicapai. Tujuan mata pelajaran IPS yang tertuang dalam standar isi yaitu: (1) mengenal konsepkonsep yang berkaitan dengan kehidupan masyarakat dan lingkungannya; (2) memiliki kemampuan dasar untuk berpikir logis dan kritis, rasa ingin tahu, inkuiri, memecahkan masalah, dan keterampilan dalam kehidupan sosial; (3) memiliki 
komitmen dan kesadaran terhadap nilai- nilai sosial dan kemanusiaan; (4) memiliki kemampuan berkomunikasi, bekerjasama dan 4). berkompetisi dalam masyarakat yang majemuk, di tingkat lokal, nasional, dan global [7]. Ruang lingkup mata pelajaran IPS meliputi aspek-aspek sebagai berikut: (1) manusia, tempat, dan lingkungan; (2) waktu, keberlanjutan, dan perubahan; (3) sistem sosial dan budaya; (4) perilaku ekonomi dan kesejahteraan[8].[9]

Dalam kita menjadi guru kita harus memahami definisi pembelajaran karena oleh beberapa ahli pembelajaran sendiri memeiliki arti yang sangat luas, pembelajaran tidak dapat didefinisikan hanya sebagai sebuah proses pemindahan pengetahuan dari seorang guru terhadap peserta didik [10,[13]]. Akan tetapi pembelajaran harus dipahami lebih luas dan lebih menyeluruh.[11]

Selain memahami definisi pembelajaran seorang guru harus mengetahui prinsip-prinsip dasar suatu disiplin ilmu agar guru tersebut mampu mengajarkan dan menyampaikan maksud dan tujuan pembelajaran tersebut [12] Sehingga seorang guru mampu membimbing murid tersebut menguasai dan memahami suatu disiplin ilmu sesuai dengan tujuan yang diharapkan masyarakat, agama dan Negara.[13]

Dalam pembelajaran IPS di SD/MI sudah seyogyanya seorang guru memahami prinsip- prinsip dasar dalam melakukan pembelajaran IPS. Prinsipprinsip ini merupakan satu kesatuan guna mencapai tujuan pembelajaran IPS bagi seluruh peserta didik.

\section{METOLOGI PENULISAN}

Dalam penelitian ini digunakan riset kepustakaan. Penelitihan pustaka atau riset pustaka ialah serangkaian kegiatan yang berkenaan dengan metode pengumpulan data pustaka, membaca dan mencatat serta mengolah bahan koleksi perpustakaan saja tanpa memerlukan riset lapangan [14]

Penelitian ini akan menampilkan argumentasi penalaran keilmuan dari hasil kajian pustaka dan hasil olah pikir peneliti mengenai suatu masalah atau topik kajian. Jenis penelitian ini didukung oleh data yang diperoleh dari sumber pustaka yang berupa jurnal penelitian, skripsi, laporan penelitian, buku teks, makalah, 
laporan seminar, diskusi ilmiah, dan lain sebagainya. Bahan-bahan pustaka tersebut dibahas secara kritis dan mendalam dalam rangka mendukung pembahasan Ilmu Pengetahuan Sosial [15]

\section{PEMBAHASAN}

Ilmu Pengetahuan Sosial (IPS) bukanlah disiplin ilmu melainkan suatu program pengajaran atau mata pelajaran yang mempelajari kehidupan sosial yang kajiannya mengintegrasikan bidang ilmu-ilmu sosial (ilmu sejarah, ilmu geografi, ilmu ekonomi, dan ilmu sosiologi) dan humaniora (aspek norma, nilai, bahasa, seni, dan budaya). Meskipun pengetahuan sosial sesungguhnya sudah melekat pada diri seseorang namun IPS perlu dipelajari dan diajarkan kepada peserta didik [17],18]. Hal ini dikarenakan pengetahuan sosial alamiah itu belum cukup mengingat kehidupan masyarakat dengan segala persoalannya itu makin berkembang. Untuk menghadapi perkembangan yang terus menerus tersebut diperlukan pendidikan formal, khususnya pendidikan IPS di sekolah [19]

Pembelajaran merupakan suatu istilah yang memiliki pengertian yang sangat luas dalam dunia pendidikan. [20] Pembelajaran dapat didefinisikan sebagai suatu sistem atau sebagai suatu proses membelajarkan peserta didik yang direncanakan atau didesain, dilaksanakan dan dievaluasi secara sistematis agar peserta didik dapat mencapai tujuan pembelajaran secara efektif dan efisien. Pembelajaran dipandang sebagai suatu sistem, berarti pembelajaran berarti sebuah komponen yang teroganisisr antara lain tujuan pembelajaran, materi pembalajan, strategi dan model pembelajaran, media pembelajaran atau alat peraga, pengorganisasian kelas, evaluasi pembelajaran, dan tindak lanjut pembelajaran [21]

Menurut Hamalik Pembelajaran adalah suatu kombinasi yang tersusun meliputi unsur-unsur manusiawi (siswa dan guru), material (buku, papan tulis, kapur dan alat belajar), fasilitas (ruang, kelas audio visual), dan proses yang saling mempengaruhi mencapai tujuan pembelajaran. [22] Proses tindakan belajar pada dasarnya adalah bersifat internal, namun proses itu dipengaruhi oleh factor-faktor eksternal. Misalnya, perhatian peserta didik dalam pembelajaran dipengaruhi oleh rangsangan yang berasal dari luar.[23],[24] 
Dalam pembelajaran pendidik harus benar-benar mampu menarik perhatian peserta didik untuk mencurahkan seluruh energinya sehingga dapat melakukan aktivitas belajar secara optimal dan memperoleh hasil belajar seperti apa yang diharapkan [25]. Pembelajaran adalah seperangkat peristiwa (events) yang mempengaruhi peserta didik sedemikian rupa sehingga sehingga peserta didik itu memperoleh kemudahan dalam berinteraksi berikutnya dengan lingkungan [26]

Pembelajaran adalah upaya untuk membelajarkan peserta didik. Istilah pembelajaran lebih tepat digunakan karena ia menggambarkan upaya untuk membangkitkan prakarsa belajar seseorang [27] Di samping itu, ungkapan pembelajaran memiliki makna yang lebih dalam untuk mengungkapkan tujuan pendekatan pembelajaran dalam upaya membelajarkan peserta didik. Sedangkan IPS adalah suatu bahan kajian terpadu yang merupakan penyederhanaan, adaptasi, seleksi dan modifikasi diorganisasikan dari konsep-konsep ketrampilanketrampilan Sejarah, Geografi, Sosiologi, Antropologi, dan Ekonomi [28]. Sulfemi menyatakan bahwa IPS merupakan mata pelajaran yang memadukan konsep-konsep dasar dari berbagai ilmu sosial disusun melalui pendidikan dan psikologis serta kelayakan dan kebermaknaannya bagi siswa dan kehidupannya [29]

Ilmu Pengetahuan Sosial (IPS) bukanlah disiplin ilmu melainkan suatu program pengajaran atau mata pelajaran yang mempelajari kehidupan sosial yang kajiannya mengintegrasikan bidang ilmu-ilmu sosial (ilmu sejarah, ilmu geografi, ilmu ekonomi, dan ilmu sosiologi) dan humaniora (aspek norma, nilai, bahasa, seni, dan budaya). Meskipun pengetahuan sosial sesungguhnya sudah melekat pada diri seseorang namun IPS perlu dipelajari dan diajarkan kepada peserta didik $\{30\}$. Hal ini dikarenakan pengetahuan sosial alamiah itu belum cukup mengingat kehidupan masyarakat dengan segala persoalannya itu makin berkembang. Untuk menghadapi perkembangan yang terus menerus tersebut diperlukan pendidikan formal, khususnya pendidikan IPS di sekolah [31]

Pendidikan IPS bertujuan "membina peserta didik menjadi warga negara yang baik, yang memiliki pengetahuan, keterampilan dan kepedulian sosial, yang berguna bagi dirinya sendiri serta bagi masyarakat dan negara". Untuk 
merealisasikan tujuan ini maka proses pembelajaran IPS tidak hanya menekankan pada aspek pengetahuan (kognitif), dan keterampilan (psikomotor) saja, melainkan meliputi juga aspek akhlak (afektif) dalam menghayati serta menyadari kehidupan yang penuh dengan masalah, tantangan, hambatan, dan persaingan [32]

Melalui pendidikan IPS peserta didik dibina dan dikembangkan kemampuan mental intelektualnya menjadi warga negara yang berketerampilan dan berkepedulian social serta bertanggung jawab sesuai dengan nilai-nilai yang terkandung dalam Pancasila. Guru IPS di SD perlu memiliki wawasan tujuan dan arah yang hendaknya dipertimbangkan ketika mengembangkan materi pembelajaran.

IPS merupakana nama salah satu mata pelajaran di tingkat Sekolah Dasar. Istilah IPS di Sekolah Dasar merupakan nama mata pelajaran yang berdiri sendiri sebagai integrasi dari sejumlah konsep disiplin ilmu sosial, humaniora, sains bahkan berbagai isu dan masalah sosial kehidupan. Materi IPS untuk jenjang Sekolah Dasar tidak terlihat aspek disiplin ilmu karena yang lebih dipentingkan adalah dimensi pedagogic dan psikologis serta karakteristik kemampuan berpikir peserta didik yang bersifat holistic.

Menurut Resnik dalam Martorrela (1991). Pembelajaran IPS adalah alih informasi pengetahuan dan keterampilan yang membantu peserta didik menempatkan diri dalam situasi yang membuatnya mampu melakukan konstruksikonstruksi pemikirannya dalam situasi wajar, alami, dan mampu mengekpresikan dirinya secara tepat apa yang mereka rasakan dan mampu melaksanakannya.

Pembelajaran Pendidikan IPS lebih menekankan pada aspek "pendidikan" daripada "transfer konsep", karena dalam pembelajaran pendidikan IPS peserta didik diharapkan memperoleh pemahaman terhadap sejumlah konsep dan mengembangkan serta melatih sikap, nilai, moral, dan keterampilannya berdasarkan konsep yang telah dimilikinya.

Dari beberapa uraian diatas dapat kita ketahui bahwa pembelajaran IPS adalah suatu sistem pendidikan yang terdiri dari berbagai faktor yang menyusun. Antara lain peserta didik, pendidik, media belajar, fasilitas belajar dan juga sumber belajar yang bertujuan membuat peserta didik menguasai dan memahami 
berbagai intregasi berbagai disiplin ilmu social. Seperti ekonomi, sejarah, sosial, geografi dan lain-lain. Selain ilmu sosial juga ilmu humaniora, sains bahkan berbagai isu dan masalah sosial kehidupan

Sehingga pembelajaran IPS di MI lebih mengutamakan mendidik peserta didik menjadi seseorang yang mampu menempatkan diri dalam situasi yang membuatnya mampu melakukan konstruksi-konstruksi pemikirannya dalam situasi wajar, alami, dan mampu mengekpresikan dirinya secara tepat apa yang mereka rasakan dan mampu melaksanakannya sesuai tingkat dan lingkungan dimana peserta didik tersebut berada.

Tujuan pembelajaran IPS di MI adalah untuk member bekal kemampuan dasar kepada peserta didik untuk mengembangkan diri sesuai bakat, minat, kemampuan dan lingkunganya dalam bidang pembelajaran di MI. Tujuan yang lebih spesifik bias ditelaan dibawah ini : 1). Mengembangkan konsep-konsep dasar sosiologi geografi, ekonomi, sejarah, dan kewarganegaraan melalui pendekatan peadagogis dan psikologis. 2) Mengembangkan kemampuan berpikir kritis dan kreatif, inkuiri, memecahkan masalah, dan keterampilan sosial. 3) Membangun komitmen dan kesadaran terhadap nilai-nilai sosial dan kemanusiaan. 4) Meningkatkan kemampuan bekerjasama dan kompetensi dalam masyarakat yang majemuk, baik secara nasional, maupun internasional.

Prinsip adalah suatu pernyataan fundamental atau kebenaran umum maupun individual yang dijadikan oleh seseorang/ kelompok sebagai sebuah pedoman untuk berpikir atau bertindak. Sebuah prinsip merupakan roh dari sebuah perkembangan ataupun perubahan, dan merupakan akumulasi dari pengalaman ataupun pemaknaan oleh sebuah obyek atau subyek tertentu Sehingga sebagai pendidik kita harus mengetahui pedoman-pedoman dasar yang menuntun atau menunjukan kita kepada tujuan sebuah pembelajaran. Begitu pula pembelajaran IPS di MI, sebagai sebuah system yang memiliki sebuah tujuan yang ingin dicapai pembelajaran IPS di MI juga memiliki pedoman dasar yang harus dipahami oleh pendidik. Agar peserta didik yang menerima pembelajaran tersebut mampu memahami dan mengaplikasikan pengetahuan yang dimiliki sesuai dengan maksud dan tujuan pembelajaran tersebut dibuat. 
Prinsip-prinsip atau pedoman dasar pembelajaran IPS di MI sebagaimana yang terdapat pada buku lapis PGMI antara lain Intregrated (terpadu), Interaksi, Kesinambungan dan perubahan, Kooperatif, Kontekstual, Problem solving, Inkuiri, Keterampilan sosial. Pertama, prinsip intregrated (terpadu). Intregrated istilah ini mirip dengan istilah integrasi atau keterpaduan, dalam KBBI intregasi (n) adalah pembaharuan hingga menjadi kesatuan yang utuh dan bulat. Dalam konteks ini integrasi adalah satu kesatuan antar disiplin ilmu sosial yang saling terkait, dengan demikian dalam penyampaian materi pembelajaran IPS dilaksanakan dengan memadukan antar disiplin ilmu yang terkait. Sehingga pembelajaran IPS dapat dilakukan berdasarkan topik yang terkait, misalnya kegiatan ekonomi penduduk dalam hal ini ditinjau dari persebaran dan kondisi fisis-geografis yang tercakup dalam disiplin geografi.

Kedua prinsip interaksi, dalam KBBI berarti hubungan, dan dalam kontek ini adalah hubungan timbal balik antara individu dengan individu, individu dengan kelompok, maupun kelompok dengan kelompok. Timbulnya interaksi disebabkan oleh dorongan saling membutuhkan dalam memenuhi kebutuhan hidup sehari-hari, baik itu kepuasan, ingin diperhatikan, dan ingin mendapat kasih sayang. Interaksi merupakan kegiatan yang menjadi kodrat seumur hidup dari manusia sebagai makhluk sosial. Sejak lahir manusia sudah memiliki naluri untuk berinteraksi dengan makhluk hidup lain. Dengan bertambahnya umur dan juga bertambah luasnya pergaulan maka interaksi yang terjadi semakin luas. Sehingga dalam konteks ini pembelajara IPS menjadi dasar yang mendidik peserta didik agar memiliki pengetahuan tentang bentuk interaksi secara umum dan juga medidik peserta didik agar mampu dan terbiasa berinteraksi dengan sesama makhluk hidup lain. Karena manusia sebagai makhluk sosial ingin hidup berkelompok dan kosekuensinya saling membutuhkan, saling bekerjasama dalam melakukan pekerjaan, saling kerjasama dalam pemecahan masalah sosial dan untuk memenuhi kebutuhan hidup bersama. Lebih dari itu dalam bekerjasama dituntut untuk saling kompromi atas keinginan pribadi demi kepentingan kelompok. Sehingga dalam pembelajaran IPS pendidik diharapkan mampu menanamkan sifat dasar ini melalui pembelajaran yang ada. 
Ketiga prinsip kesinambungan dan perubahan. Dalam kehidupan bermasyarakat manusia akan selalu terikat dengan adat dan tradisi yang sudah ada dan diwariskan dari generasi sebelumnya. Pewarisan ini akan berlangsung dari satu generasi ke generasi yang selanjutnya. Sebagai contoh kesinambungan kehidupan itu terjadi karena lembaga perkawinan.

Seperti halnya uraian diatas pembelajaran IPS juga harus bersinambung karena pada dasarnya materi dan pemahaman peserta didik harus sambungmenyambung, sehingga peserta didik lebih mudah dan cepat memahami materi yang disampaikan. Sebagai contoh materi sejarah ketika tidak berkesinambungan akan membuat peserta didik kebingungan memahami alur dan hubungan sebab akibat peristiwa sejarah tertentu.

Selain harus bersinambung pembelajaran IPS juga harus mengikuti perubahan. Hal ini karena manusia sebagai obyek utama pembelajaran IPS terus mengalami perubahan sesuai dengan berjalanya waktu serta perkembangan ilmu pengetahuan dan teknologi. Tidak ada individu, kelompok atau masyarakat yang berhenti berproses. Misalnya apabila kebudayaan suatu masyarakat berubah, baik besar maupun kecil maupun kecil maka masyarakar yang mempunyai kebudayaan tersebut juga akan mengalami perubahan sesuai dengan perubahan yang terjadi. Perubahan sosial ini bias terjadi karena politik, ekonomi, ataupun kemajuan teknologi dengan skala yang berbeda-beda tiap masyarakat di daerah satu dengan daerah lainya. Sehingga dalam mengajarkan IPS pendidik harus mengikuti dan melacak perubahan-perubahan yang terjadi sehingga para peserta didik mampu mengambil nilai-nilai yang terkandung.

Keempat prinsip kooperatif. Kooperatif dalam KBBI berarti bekerjasama atau membantu. Dalam pembelajaran kita mengenal cooperative learning yaitu system pembelajaran yang member kesempatan pada peserta didik untuk salin berinteraksi dan bekerja sama dengan peserta didik lain. Dalam cooperative learning ada struktur dorongan atau tugas yang bersifat kooperatif, sehingga memungkinkan peserta didik untuk berinteraksi secara terbuka dan hubungan yang bersifat interdependensi efektif diantara anggota kelompok. Dalam pembelajaran IPS siswa dilatih memahami hubungan sosial secara langsung dalam 
proses pembelajaran, dan pendidik dapat menggunakan system/strategi cooperative learning ini sebagai salah satu pembelajaran langsung dalam proses pebelajaran.

Menurut sanjaya cooperative learning memiliki empat prinsip dasar sebagai berikut : Pertama, Prinsip Ketergantungan Positif. Kerja kelompok adalah kerja tim, yaitu keberhasilan dari tugas kelompok tersebut tergantug pada keberhasilan semua individu dalam kelompok tersebut. Dan keberhasilan tim tersebut tergantung sejauh mana anggota kelompok tersebut memahami dan tanggung jawabnya terhadap tugas yang diberikan kepadanya. Oleh karena itu setiap anggota tergantung dengan anggota yang lainya dan dari keteragntungan ini keberhasilan kelompok ditentukan. Inilah yang disebut ketergantungan positif [33]

Kedua, tanggung Jawab Perseorangan. Keberhasilan kelompok tergantung dari keberhasilan setiap individu. Sehingga setiap anggota kelompok harus memiliki tanggung jawab terhadap kewajiban yang diberikan kepadanya. Implikasinya dalam evaluasi guru harus memberikan penilaian terhadap individu tida hanya terhadap kelompok [37]

Ketiga, Interaksi Tatap Muka. Implementasi cooperative learning member ruang kepada setiap individu dalam kelompok untuk saling memberikan informasi dan membelajarkan seluas-luasnya dengan anggota lainya dalam kelompok. Interaksi tatap muka akan memberi pengalaman yang berharga kepada setiap anggota kelompok untuk bekerjasama, manghargai setiap perbedaan memanfaatkan kelebihan setiap anggota, dan mengisi kekurangan masing- masing anggota.

Keempat, Partisipasi dan Komunikasi. Tujuan utama cooperative learning adalah melatih setiap peserta didik untuk berpartisipasi aktif dan berkomunikasi dengan baik. Dengan cooperative learning diharapkan siswa mampu mengembangkan kemampuan dasar dalam berkomunikasi seperti mengemukakan pendapat, bertanya, menjawab, menyatakan setuju, dan menyanggah pernyttaan temanya dengan santun dan tidak memojokan temanya.

Kelima, kontekstual. Salah satu prinsip dasar pembelajaran IPS adalah kontekstual yaitu dalam proses pembelajaran peserta didik diarahkan untuk belajar 
tidak hanya dari materi yang bersumber dari buku akan tetapi dari materi yang bersifat ada disekitar peserta didik baik lingkup keluarga, teman sebaya, maupun lingkungan lain. Dengan belajar dari segi lingkungan dan kehidupan disekitar peserta didik, diharapkan mereka mampu menjadi peserta didik yang mandiri. Mendorong mereka belajar dari sesama teman yang mempunyai latar belakang dan keadaan yang berbeda-beda dan juga memahami lingkungan yang berbedabeda [38]. Sehingga peserta didik dapat lebih memahami kedaan sosial di sekitar mereka secara pasti (autentik), karena dalam pembelajaran kontekstual ditekankan menggunakan penilaian autentik (authentic assessment). Lebih lanjut untuk memahami dan memperoleh hasil yang maksimal maka pembelajaran kontekstual menekankan pada tujuh pilar kontekstual, yaitu. Kontruktivisme, maksudnya peserta didik diberi kesempatan untu membangun sendiri pengetahuanya bukan menerima saja dari guru. Inkuiri, adalah pengetahuan diperoleh dengan menemukan melalui pengalaman sendiri. Bertanya, adalah belajar dengan kegiatan produktif, menggali informasi, menghasilkan pengetahuan. Masyarakat belajar, adalah kerjasama, maju bersama, dan saling membantu. Pemodelan, maksudnya pembelajaran yang multi way (jalur yang banyak), mencoba hal-hal baru yang kreatif. Refleksi, adalah pembelajaran yang komprehensif, evaluasi diri secara internal dan eksternal. Penilaian autentik, penilaian proses dan hasil, tes dan non tes, multi aspek. [34]

Keenam, problem Solving. Selanjutnya dalam pembelajaran IPS di SD/MI peserta didik juga di didik supaya mampu mengetahui, memahami, mencari solusi dalam masalah sosial yang terjadi pada diri peserta didik beserta lingkungan disekitarnya. Karena dalam pembelajaran berbasis masalah peserta didik dilibtkan meneliti informasi yang spesifik untuk sampai pada kesimpulan yang belum ditetapkan sebelumnya.

Dalam pendekatan berbasis problem peserta diminta untuk : 1) Menarik pengetahuan dari satu wilayah disiplin ilmu tertentu. 2) Menggunakan pengetahuanya sendiri secara tepat. 3) Menerapkan pengetahuanini dalam serangkaian tantangan 4) Mereaksi secara tepat terhadapproblem yang muncul, 5) Mencapai solusi yang telah dipertimbangkan dengan berdasar kepada alasan yang 
dibenrkan. [35]

Ketujuah Inkuir, prinsip inkuiri merupakan suatu pendekatan pembelajaran yang menuntut peserta didik untuk mencari dan menemukan sendiri sesuatu yang baru sebagai hasil belajar.[36] Pendekatan Inkuiri adalah suatu perluasan prosesproses discovery yang digunakan dalam cara yang lebih dewasa. Salah satu prinsip dalam pembelajaran IPS di MI ini bertujuan merangsang kemampuan bertanya, menyelidiki, meneliti, untuk mengembangkan berfikir kritis dan mengembangkan kemampuan berfikir peserta didik. Dalam konteks ini pendidik diharapkan mampu mengembangkan pembelajaran IPS sebagai proses pembelajaran yang mampu merangsang kemampuan bertanya, menyelidiki, meneliti, untuk mengembangkan berfikir kritis dan mengembangkan kemampuan berfikir peserta didik. Bertitik tolak pada persoalan-persoalan itu peserta didik dirangsang kemampuan bertanya, menyelidiki, meneliti. Melalui cara inipeserta didik dirangsang berfikir kritis dan mengembangkan kemampuan berfikirnya. Model ini mengajar peserta didik untuk bekerja di dalam kelompoknya untuk menginvestigasi topik-topik yang kompleks. Maksudnya bahwa kemampuan untuk mengikuti dan menyelesaikan tugas-tugas dalam kelompok adalah penting baik dalam lingkunga kelas maupun luar kelas. [39].

Kedelapan, keterampilan sosial. Pendekatan keterampilan proses, bertujuan menumbuhkan keterampilan yang berkaitan dengan sutu proses tertentu yang perlu dilatihkan. Menanamkan perilaku tertentu biasanya perlu dilatih dan dibiasakan sehingga nanti akan muncul perilaku yang diharapkan dalam bermasyarakat. Keterampilan proses bisa dimulai dari mencari informasi sampai nanti bisa menginformasikannya. Sumber-sumber menumbuhkan keterampilan proses dalam pembelajaran IPS antara lain peta, globe, gambar atau foto, grafik, diagram dan sebagainya [33]

Kesadaran terhadap manfaat yang akan diberikan anak-anak melalui proses dan hasil akhir kegiatan mereka akan memberikan kita kemampuan untuk mengartikulasikan manfaat- manfaat ini dan untuk menggunakan display sekolah dan rapat staf sekolah untuk mempromosikan contoh-contoh kualitas pembelajaran anak-anak. Dalam konteks pembelajaran IPS keterampilan yang 
harus di ketahui dan dikuasai oleh peserta didik adalah keterampilan sosial yaitu keterampilan-keterampilan bekerjasama, bergotong-royong, tolong menolong, dan lain sebagainya. Jadi dalam pengertian ini keterampilan sosial adalah keterampilan peserta didik dalam melakukan kegiatan-kegiatan makhluk sosial guna memenuhi kebutuhan masyarakat.

\section{KESIMPULAN}

Pembelajaran Pendidikan IPS lebih menekankan pada aspek "pendidikan" daripada "transfer konsep", karena dalam pembelajaran pendidikan IPS peserta didik diharapkan memperoleh pemahaman terhadap sejumlah konsep dan mengembangkan serta melatih sikap, nilai, moral, dan keterampilannya berdasarkan konsep yang telah dimilikinya. Sehingga mampu mengarahkan peserta didik menjadi pribadi yang mandiri, kritis, kreatif dan adaptif.

Sedangkan tujuan pembelajaran IPS di MI adalah untuk member bekal kemampuan dasar kepada peserta didik untuk mengembangkan diri sesuai bakat, minat, kemampuan dan lingkunganya dalam bidang pembelajaran di MI. Dalam pembelajaran IPS di MI seorang guru memahami prinsip-prinsip dasar dalam melakukan pembelajaran IPS. Prinsip-prinsip ini merupakan satu kesatuan guna mencapai tujuan pembelajaran IPS bagi seluruh peserta didik.

Prinsip-prinsip dasar pembelajaran sebagai berikut :1) Intregrated (terpadu), 2) Interaksi, 3) Kesinambungan dan perubahan, 4) Kooperatif, 5) Kontekstual, 6) Problem solving, 7) Inkuiri, dan 8) Keterampilan sosial

\section{DAFTAR PUSTAKA}

[1] Sulfemi, Wahyu Bagja. (2019). Menanggulangi Prilaku Bullying Di Sekolah. Bogor : Visi Nusantara Maju

[2] Sulfemi, Wahyu Bagja. (2018). Manajemen Kurikulum di Sekolah. Bogor : Visi Nusantara Maju

[3] Palettei, A. D., \& Sulfemi, Sulfemi, W. B. (2019). Pengaruh Kelompok Kerja Guru (KKG) Terhadap Peningkatan Kompetensi Pedagogik dan Kemampuan Menulis Karya Ilmiah. Jurnal Pendidikan Dasar Indonesia Jurnal Pendidikan Dasar Indonesia (JPDI). 7 (2). 53 - 58. DOI: http://dx.doi.org/10.26737/jpdi.v4i2.1522 
[4] Sulfemi, Wahyu Bagja. (2018). Modul Manajemen Pendidikan Non Formal. Bogor : STKIP Muhammadiyah Bogor.

[5] Sulfemi, Wahyu Bagja. (2016). Perundang-Undangan Pendidikan. Bogor : Program Studi Administrasi Pendidikan STKIP Muhammadiyah Bogor.

[6] Sulfemi, Wahyu Bagja dan Lestari, Ayu Hopilatul. (2017). Korelasi Kompetensi Pedagogik Guru dengan Prestasi Belajar Mata Pelajaran IPS Di SMP Muhammadiyah Pamijahan Kabupaten Bogor. Edutecno. 16 (1), 1-16

[7] Tim Penyusun Jurusan Pendidikan Pengetahuan Sosial FPIPS UPI. 2010. Pendalaman Materi dan Metodologi Pembelajaran Ilmu Pengetahu Sosial $S D / M I$.

[8] Sulfemi, Wahyu Bagja dan Nurhasanah. (2018). Penggunaan Metode Demontrasi dan Media Audio Visual Dalam Meningkatkan Hasil Belajar Peserta Didik Mata Pelajaran IPS. Jurnal Pendas Mahakam. 3 (2). 151-158. https://jurnal.fkipuwgm.ac.id/index.php/pendasmahakam/article/view/229.

[9] Sulfemi, Wahyu Bagja dan Abdul Qodir. (2017). Hubungan Kurikulum 2013 Dengan Motivasi Belajar Peserta Didik Di SMK Pelita Ciampea. Edutecno 17 (2), 1-8.

[10] Beetlestone, Florence. 2012. Creative Learning. Bandung: Nusa Media. Suhada, Idad. 2010. Pendidikan IPS di SD/MI. Bandung: Solo Press.

[11] Sulfemi, Wahyu Bagja dan Yuliani, Nunung. (2019). Model Pembelajaran Contextual Teaching And Learning (CTL) Berbantu Media Miniatur Lingkungan Untuk Meningkatkan Hasil Belajar IPS. Edunomic. 7 (2). 73 84. DOI : 10.33603/ejpe.v7i2.1970.

[12] Sulfemi, W. B., \& Kamalia, Y. (2020). Jigsaw Cooperative Learning Model Using Audiovisual Media To Improve Learning Outcomes. JPsd (Jurnal $\begin{array}{lllll}\text { Pendidikan Sekolah } & \text { Dasar). } & 6 & \text { (1), }\end{array}$ DOI: http://dx.doi.org/10.30870/jpsd.v6i1.4919

[13] Sulfemi, Wahyu Bagja dan Abdul Qodir. (2017). Hubungan Kurikulum 2013 Dengan Motivasi Belajar Peserta Didik Di SMK Pelita Ciampea. Edutecno 17 (2), 1-8.

[14] Saifuddin Azmar, (2001). Metode Penelitian, Yogyakarta: Pustaka Pelajar

[15] Sulfemi, Wahyu Bagja. (2018). Modul Manajemen Pendidikan Non Formal. Bogor: STKIP Muhammadiyah Bogor

[16] Sulfemi, Wahyu Bagja. (2017). Korelasi Penilaian Guru Terhadap Gaya Kepemimpinan Asertif Kepala Sekolah Dengan Kinerja Guru Di SMPN 01 Jasinga Kabupaten Bogor. Lingua : Jurnal ilmiah Kajian Pendidikan Bahasa dan Sastra Indonesia. 3 (1) 201 7. 90-100

[17] Sudirman, dkk. 1990. Ilmu Pendidikan. Bandung: Remaja Rosdakarya.

[18] Sulfemi, Wahyu Bagja. (2019). Model Pembelajaran Kooperatif Mind Mapping Berbantu Audio Visual Dalam Meningkatkan Minat, Motivasi dan 
Hasil Belajar IPS. Jurnal PIPSI (Jurnal Pendidikan IPS Indonesia), 4(1), 13-19. DOI: http://dx.doi.org/10.26737/jipips.v4i1.1204.

[19] Sulfemi, W. B., \& Mayasari, N. (2019). Peranan Model Pembelajaran Value Clarification Technique Berbantuan Media Audio Visual Untuk Meningkatkan Hasil Belajar IPS. Jurnal Pendidikan. 20 (1). 53-68. Doi : https://doi.org/10.33830/jp.v20i1.235.2019

[20] Sulfemi, W. B. (2018). Pengaruh Disiplin Ibadah Sholat, Lingkungan Sekolah, dan Intelegensi Terhadap Hasil Belajar Peserta Didik Mata Pelajaran Pendidikan Agama Islam. Edukasi: Jurnal Penelitian Pendidikan Agama dan Keagamaan. 16 (2), 166-178. DOI: 10.32729/edukasi.v16i2.474.

[21] Sulfemi, Wahyu Bagja., \& Desmiati, Z. (2018). Model Pembelajaran Missouri Mathematics Project Berbantu Media Relief Experience dalam Meningkatkan Hasil Belajar Siswa. PENDAS MAHAKAM: Jurnal Pendidikan Dasar, 3(3), 232-245. https://jurnal.fkipuwgm.ac.id/index.php/pendasmahakam/article/view/269/173

[22] Hamalik, Oemar. (2011). Proses Belajar Mengajar. Jakarta: PT Bumi Aksara.

[23] Sulfemi, Wahyu Bagja. (2018). Hubungan Motivasi Belajar Dengan Hasil Belajar IPS Di SMP Kabupaten Bogor. Edutecno 18 (2), 1-8.

[24] Sulfemi, W. B., \& Minati, H. (2018). Meningkatkan Hasil Belajar Peserta Didik Kelas 3 SD Menggunakan Model Picture And Picture dan Media $\begin{array}{llllll}\text { Gambar Seri. } & \text { JPSD. } & 4 & \text { (2), }\end{array}$ DOI: http://dx.doi.org/10.30870/jpsd.v4i2.3857.

[25] Arsyad, Arsyad dan Sulfemi, Wahyu Bagja. (2018) Metode Role Playing Berbantu Media Audio Visual Pendidikan dalam Meningkatkan Belajar IPS. Jurnal Pendidikan Ilmu Pengetahuan Sosial Indonesia. 3 (2). 41 - 46. DOI: http://dx.doi.org/10.26737/jpipsi.v3i2.1012.

[26] Sulfemi, Wahyu Bagja. (2017). Analisis Pengaruh Motivasi Dan Disiplin Terhadap Kinerja Guru (Studi Kasus di SMA Negeri 1 Pamijahan Kabupaten Kabupaten Bogor). Prosiding Seminar Nasonal STKIP Muhammadiyah Bogor. 1 (1), 342-357

[27] Puskur, (2000). Kurikulwn Berbasis Kompetensi, Mata Pelajaran Sains Sekolah. Dasar. Jakarta.

[28] Sulfemi, Wahyu Bagja dan Supriyadi, Dede. (2018). Pengaruh Kemampuan Pedagogik Guru dengan Hasil Belajar IPS. Edutecno 17 (1), 1-10.

[29] Sulfemi, Wahyu Bagja dan Setianingsih. (2018), Penggunaan Tames Games Tournament (TGT) Dengan Media Kartu Dalam Meningkatkan Hasil Belajar. Journal of Komodo Science Education (JKSE). 1 (1), 1-14.

[30] Wahab, Abdul Azis (2008). Konsep Dasar IPS. Jakarta : Universitas Terbuka 
[31] Sulfemi, Wahyu Bagja. (2019). Manajemen Pendidikan Berbasis Multi Budaya. Bogor : STKIP Muhammadiyah Bogor.

[32] Purwana, Agung Eko dkk. 2009. Lapis PGMI Pembelajaran IPS di MI. Surabaya: Aprint A http://ishmacassi.blogspot.com/2013/03/pendekatanpembelajaran-ips-di-sdmi.html

[33] Sanjaya, Wina. (2011). Strategi Pembelajaran Berorientasi Standar Proses Pendidikan. Jakarta: Prenada Media Group.

[34] Sulfemi, Wahyu Bagja., \& Desmiati, Z. (2018). Model Pembelajaran Missouri Mathematics Project Berbantu Media Relief Experience dalam Meningkatkan Hasil Belajar Siswa. Pendas Mahakam: Jurnal Pendidikan Dasar, 3(3), 232-245. 2ttps://jurnal.fkipuwgm.ac.id/index.php/pendasmahakam/article/view/269/173.

[35] Muhaimin. 2004. Paradigma Pendidikan Islam. Bandung: Remaja Rosdakarya.

[36] Arsyad, Arsyad., \& Sulfemi, Wahyu Bagja. (2019). Korelasi Penguasaan Materi Pembelajaran Oleh Guru Dengan Motivasi Belajar Siswa Mata Pelajaran Administrasi Perkantoran di SMK Pelita Bogor. Edutecno. 20 (2), $1-10$.

[37] Sulfemi, Wahyu Bagja. (2019). Menanggulangi Prilaku Bullying Di Sekolah. Bogor : Visi Nusantara Maju

[38] Sulfemi, Wahyu Bagja., \& Luthfianti, Teti. (2019). Asosiatif Layanan Tenaga Perpustakaan Sekolah dengan Motivasi Membaca Siswa di Kabupaten Bogor. Edutecno, 19(2), 1-10.

[39] https://bagawanabiyasa.wordpress.com/2013/05/16/pembelajaran-ips-di-sd/ 